\title{
B er ichtigung.
}

$$
\text { Von }
$$

\section{Dr. K. Bülow.}

Durch ein Versehen ist in dem dritten Theil der Arbeit: "Ueber die dextrinartigen Abbauproducte der Stärke", dieses Archiv Bd. 62 pag. 144 und folgende in der Correctur iuberall statt der richtigen Schreibweise "Achroodextrin“ Acheroodextrin stehen geblieben. Es ist somit iiberall statt Acheroodextrin „Achroodextrin" zu lesen. 